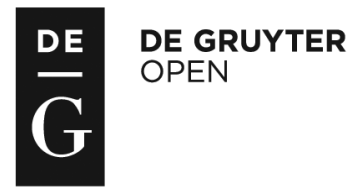

Administration, vol. 65, no. 3 (2017), pp. 101-121

doi: 10.1515/admin-2017-0026

\title{
Gender budgeting in Europe: What can we learn from best practice?
}

\author{
Sheila Quinn \\ Gender Equality \& Human Rights Specialist, Ireland
}

\section{Introduction}

Gender budgeting in Europe has attracted considerable attention over the last few decades. A burgeoning momentum during the early 2000s saw a full range of stakeholders promote a broad swathe of activities under the rubric of gender budgeting. At that time there was an expectation that gender budgeting would 'liberate' and 'elevate' gender, and gender mainstreaming, to the level of macroeconomic policy and thus expedite the realisation of oft-projected gender equality goals (Holvoet, 2006). In return, advocates offered that it would contribute to the goals of efficiency, economy and effectiveness (Sharp, 2003).

This paper provides an overview of gender budgeting in Europe, with a particular focus on institutional mechanisms and operational methodologies. In some instances, national and regional governments have legislated for gender budgeting (viz. Austria, Belgium, Andalucía), many have initiated changes to the institutions of the budget (viz. Albania, Belgium, Iceland), while others have recommitted to the fundamental concept of marrying equality policy with economic policy (viz. Sweden, Finland, Iceland). Alongside this, civil society organisations have brought the focus squarely on revenue policy, particularly taxation, and on welfare benefits. 
An expanded version of this paper (Quinn, 2016), based on research commissioned by the International Monetary Fund (IMF), was presented at an IMF conference on Fiscal Policy and Gender Equality in Washington, DC, in November 2016, where Christine Lagarde committed the organisation to taking forward gender budgeting within its Fiscal Affairs Department, including within the context of its Article IV country consultations. This commitment comes at a time when a return to economic growth holds the promise of a restoration of the equality agenda in many European countries.

This discussion of gender budgeting across Europe is mindful of the influence of EU policy and directives. On aggregate, the EU has had a positive influence on the development of gender equality policy, not only on its member states but also on other European countries, where candidacy for accession or other aid-related relationships require countries to work towards compliance with EU norms. While some countries have retreated from full compliance in the post-accession period, the legislative harmonisation brought about by the implementation of the Employment and Social Affairs Chapter of the acquis communautaire has legitimised women's claim to genuine equality (Sloat, 2004).

Nevertheless, there has been concern about the weakening of the EU's social agenda, including its gender equality policy, for some time, and certainly prior to the most recent financial and public debt crises (Crouch, 2015). The most recent changes to the European Employment Strategy - the principal gender equality instrument because of its economic focus - left gender equality sidelined to the preamble and put the focus squarely on men's employment, seemingly overlooking the gains made in raising women's employment during the Lisbon process (Villa \& Smith, cited in Barry, 2014).

\section{Case studies}

\section{Austria}

In Austria gender budgeting was introduced as part of a broader budgetary reform process. New legislation and a constitutional amendment in 2007 paved the way for a comprehensive reform of the budgetary process with the move to performance-oriented budgeting by 2013. As part of the reform, gender equality became one of four constitutionally mandated budgetary principles; the others are transparency, efficiency, and a true and fair view of the financial position of the federal government of Austria. These characteristics 
render Austria's gender budgeting initiative one of the most institutionally robust in Europe, and arguably provide a strong legislative basis for a refinement of its methods so as to effect more substantive gender equality outcomes in line with socioeconomic priorities. The main methodological tool for gender budgeting in Austria is the identification of a gender equality objective for each budget chapter. A weakness of Austria's approach is a built-in disincentive to the identification of relevant and potentially transformative gender equality objectives. A 2015 evaluation showed that budget personnel, while expressing commitment to the goal of gender equality, in the main lacked capacity for meaningful gender analysis.

A spring 2015 evaluation of the reform process touched briefly on the gender budgeting dimension. The evaluation was based on interviews with budget officials. While the majority of respondents were positive about the integration of gender equality, many questioned its prominent equal standing as one of a maximum of four outcome objectives. Respondents felt that, at this early stage in the reform process, it was unrealistic to give the same weight to gender equality as to other dimensions of reform. They also felt that gender equality was not being well served in this respect. The evaluation drew attention to the poorly specified gender equality targets that did not reflect the complexity of the subject. As an example, indicating that women should constitute 50 per cent of any given target group is a poorly conceived gender equality objective. Thus, goals are not sufficiently ambitious and a lack of data means that the gender equality objectives are not being subject to evaluation, thus the control of outcomes is inoperable (Hammerschmid \& Grunwald, 2014).

\section{Belgium}

Belgium's gender budgeting initiative is also underpinned by law. Whereas in Austria the law is about reform of public finance, in the case of Belgium the law was introduced to give effect to the country's commitment to gender mainstreaming. Notable in the Belgium case is the specificity of the law, which mandates: (i) methodologies and processes to integrate gender equality into all budgetary processes, (ii) the collection and management of gender-relevant data, (iii) the specification of gender equality objectives in line with the Beijing Platform for Action (BPfA) and (iv) the application of gender budgeting to government procurement. A strength of Belgium's initiative is the alignment of its gender equality objectives with the 
BPfA, a framework that comprehends all aspects of gender equality relevant to government policy (Quinn, 2013). Also notable is a 2001 conference, co-hosted with the OECD, UNIFEM (UN Development Fund for Women) and the Nordic Council of Ministers, when Belgium held the presidency of the EU. The conference was instrumental in putting gender budgeting on the agenda across Europe. Implementation of this multifaceted, institutionally robust gender budgeting programme has been hampered somewhat by the prevalence of federal government vacancy during the last decade.

In addition to the gender note, the law stipulates the application of a 'gender test': an assessment of the potential differential impact on women and men of all government policies, laws and measures perceived to have significant relevance to gender equality. An important element of the law is the mandate to collect and manage sex-disaggregated data and to develop gender indicators. These are to be used for the purpose of measuring progress on gender equality and should be reported on within the annual budgetary documentation and during the budget debate.

\section{Sweden}

Following elections in September 2014, the new government declared itself a feminist government and, among other gender equality commitments, outlined its intention to institute gender budgeting in the programme for government presented to Parliament by the Prime Minister. It is instructive to understand this commitment to gender budgeting in the context of Sweden's previous efforts to mainstream a gender perspective in its budgetary processes and policies.

Statistics Sweden has had a gender equality unit since 1982, and since 1984 has published Women and Men in Sweden: Facts and Figures biennially. In 1994 the Ordinance on Official Statistics mandated that all official statistics related to individuals be disaggregated by sex. Following a review in 2006, the use of sex-disaggregated statistics in the budget bill became more widespread, in keeping with a government goal of improving policy outcomes (Government Offices of Sweden, 2006).

In relation to gender mainstreaming in the budget, the Ministry of Finance initiated the project An Equal Share in 2002. This was wound up in 2004 and gender budgeting was subsumed into the new Plan For Gender Mainstreaming, 2004-2009, signalling that gender budgeting was to become part of the regular work of gender mainstreaming. A central goal of the plan was to integrate a gender analysis into the "two 
central decision-making processes in the Government Offices - the legislative process and the budget process' (Government Offices of Sweden, 2006, p. 7). This renewed focus led to the development of range of methodologies, overseen by the JamStod Committee, for which Sweden has become renowned and which has been influential across Europe and beyond.

Since 2016, the annual budget circular has included instructions on the application of gender budgeting throughout the budget process. Among the requirements set out in the circular is that gender impact analysis be carried out at the early stage of new budget proposals. In addition, sex-disaggregated data are to be used and new gender equality indicators devised to reflect current status. This new government initiative is seen as strengthening gender mainstreaming in the budgetary process through improved mechanisms for internal management and control, an improved methodology (JamKas) and better use of sex-disaggregated data. The initiative should also result in a more advanced gender equality impact analysis.

\section{Iceland}

Iceland's first experience with gender budgeting was a pilot project undertaken within the framework of the Nordic Co-operation in 2006. In 2009 the new coalition government adopted gender budgeting as a key element in the preparation of the budget and of economic policy. During this period (2010-11) each government department was obliged to undertake a pilot project with the goal of establishing the scope and parameters of a viable methodology. An attendant goal was to gauge the adequacy of existing gender data. These early pilot projects included analysis of the transferability of personal tax discounts between couples by the Ministry of Finance, research on the debt status of Icelandic households by the Ministry of Economic Affairs, and analysis of the gender distribution of unemployment benefits and hospital waiting lists by the Ministry of Welfare.

The government approved a three-year plan for gender budgeting in 2011, calling on all ministries to choose one main policy area with which to work, while continuing with pilot projects. The emphasis was on measures designed to bring about economic recovery and the need to apply gender budgeting tools to planned public expenditure cuts, as well as to job-creation measures (Government of Iceland, 2011). Article 16 of the Equal Status Act, 2008, mandates the use of sexdisaggregated statistics in all official economic surveys and in subsequent reports and policymaking. 
In late 2015 the Government of Iceland approved a new five-year plan on gender budgeting, with the overall objective of making the methodologies more integral to the decision-making process within government. The new plan has three broad emphases:

i. measuring short-term outcomes and amending plans to ensure that targets are reached;

ii. gender impact analysis of all new budget proposals;

iii. analysis of all new legislative proposals to include a cost-benefit analysis from a gender perspective.

While the new plan does not make specific mention of tax policy, this dimension will be covered by the gender analysis of new legislative proposals.

To bolster the new gender budgeting plan, the new organic budget law (OBL), which came into effect in January 2016, assigns responsibility to the Minister of Finance, working in consultation with the Minister for Equality. In addition, the OBL mandates that gender budgeting is taken into account in the drafting of the Budget Bill and that the Budget Bill shall detail the impact of the budget on the attainment of gender equality targets. Instructions on gender budgeting have been included in the budget circular since 2010 .

\section{Regional initiatives}

\section{Berlin}

In Berlin gender budgeting has been in operation as tool of gender mainstreaming since 2003, following a decision by the Berlin House of Representatives in 2002 - a decision due in large measure to the support of women parliamentarians, as well as strong advocacy from civil society. The Department of Finance takes the lead on gender budgeting, working closely with the Department for Labour, Integration and Women.

In the beginning the objective was to render the budget transparent in terms of a gender-differentiated use of public finds. Moving beyond the use of sex-disaggregated data, the House of Representatives sought to deepen the gender analysis within the budget. A third stage of the model employed in Berlin moved towards being able to 'steer' or re-orient budgetary expenditure towards the achievement of specific gender equality objectives. 
The most recent budget (2016/17) for the Senate of Berlin demonstrates the enhanced level of gender-related information used within the budgetary process. Each departmental chapter opens with a section dealing with objectives and priorities, a breakdown of revenue and expenditure, and other general considerations. Included are instructions on the function of gender budgeting as a 'Ministerial control function' that complements the 'principles of sustainable fiscal policy' by helping to ensure public resources are targeted efficiently (Senate Department for Labor, Integration and Women, 2016).

Each budget chapter begins with a sex-disaggregated breakdown of public officials. In addition, the mean monthly salary is disaggregated by sex with an indication of the gender gap in salary. This is accompanied by an explanation for the gender gap. The explanation points to the predominance of men in the higher salary brackets and to women having to take maternity leave and so interrupt their career progression. Analysis of the data indicates whether the sex distribution of beneficiaries matches the actual target group and, if not, what measures are planned to 'steer' the outcome so as to achieve gender equality.

There is some concern, however, that the new steering tool has not yet gone far enough to move the Berlin approach qualitatively beyond disaggregating beneficiaries by sex. This was the approach for ten years and the challenge now is expanding a methodology that has already become institutionalised and 'locked in' its own path dependency. Dr Gabriele Kämper, Head of the Equality Division in the Senate Department for Labour, Integration and Women, points to the challenge of gender expertise residing within her department, which is one part of the ministerial collaboration coordinating gender budgeting. In reality the day-to-day operations fall to the Senate Department of Finance, where the officials, while enthusiastic about gender budgeting, lack the gender expertise needed.

On the other hand, a clear strength of the Berlin initiative is its political underpinning and its endurance over a period of twelve years (Quinn, 2015).

\section{Andalucía}

Gender budgeting in Andalucía has a strong legal basis, beginning with a 2003 Fiscal and Administrative Measures Law, and reinforced over the years by other primary legislation and regulations. The 2003 law established two gender budget provisions: the requirement that the regional budget presented to parliament contain a gender impact 
report (GIR), and secondly the establishment of a Gender Impact Commission (GIC) within the Ministry of Finance. The 2007 law on gender equality mandates the publication of the GIR for the draft finance bill - and, importantly, for the collection and management of sex-disaggregated and gender-relevant data. The Finance Law of 2010 mandates that the GIR is attached to the annual budget law. In addition, further government decrees have solidified the role of the GIC. Finally, the Statute of Autonomy mandates the application of a gender impact assessment for all new laws and provisions, including the finance bill.

As with Berlin, gender budgeting is seen as the primary vehicle for the implementation of gender mainstreaming in Andalucía. In addition, the regional government, keen to succeed as an autonomous region, and in particular to reverse the fortunes of one of the poorest regions in Spain, has adopted gender budgeting as part of its strategy for economic growth and competitiveness (O'Hagan, 2015). In effect, gender budgeting is now perceived as a tool of modern governance.

The Andalucía gender budgeting exercise is notable for the roundedness of organisation. The Ministry of Finance has taken the lead since its inception, initiating an ongoing deepening of the methodologies and processes, and ensuring the integration of the practice within the regular budgetary institutions. The first GIR was produced in 2005, but was for internal use only and therefore not published. In 2007 the $\mathrm{G}+$ Programme was introduced: the aim is to prioritise those budget programmes that are most relevant to, and capable of, advancing gender equality. Presented as a three-stage methodology, the first stage of identifying and classifying budgetary programmes according to the $\mathrm{G}+$ scale is key. All budget programmes are ranked, from those deemed not gender relevant at all to those seen as having the most potential to effect gender equality.

The second stage of the $\mathrm{G}+$ Programme involves preparing a strategic guidance document for each budgetary programme (with the exception of those ranked not gender relevant). Made operational in 2010 , this acts as a 'living' document, a record of early analysis and of progress in relation to indicators and goals.

In 2013 the provision for gender audits (evaluations) contained in the 2003 Fiscal And Administrative Measures Law was enacted. Five $\mathrm{G}+$ Programmes were assessed in terms of effectiveness in attaining gender equality goals, as well as the degree to which the associated processes of planning and implementation were gender mainstreamed. A report of the results published in October 2015 
concluded, 'gender mainstreaming in the budgeting process and activities has increased during the period 2009-2012 in relation to the work existing prior to this date' (Gualda et al., 2015). An important follow-up to the audit process will be the planned public consultation process. Those charged with oversight of the gender budgeting process acknowledge the need to engage with civil society, a dimension which to date has been missing in the Andalucía exercise.

\section{Gender budgeting and revenue policy}

The practice of gender budgeting across Europe is almost exclusively associated with the expenditure side of the budget, and in particular with expenditure related to the delivery of public services. This restrictive application of gender budgeting, with a lack of focus on revenue and income transfers and on macro-level budgetary decisions, including those relating to debt and deficits, excludes important dimensions of fiscal policy with the potential for a significant impact on gender equality.

Between the 1970s and 1980s most European countries removed explicit discrimination against women from their tax codes. Today, the personal income taxes in most European countries are gender neutral and, for the most part, taxation is on an individual basis. Some countries, however, still use some form of joint taxation, including Germany, France and Portugal. It has been observed, for example, that in Germany the system of 'income splitting', for the purpose of joint filing, privileges couples on higher incomes and also works to reinforce the male breadwinner model, and thus impedes gender equality through women's economic independence (Betzelt \& Bothfeld, 2011; Palier \& Thelen, 2010).

When it comes to sales-type taxes (e.g. VAT and excises), the bias is more implicit in nature, because taxation applies to the sale of a good or service. However, there are important design issues with a bearing on gender (Grown, 2010). For instance, applying reduced VAT rates (either through zero rating, exemptions or lower-thanstandard rates) on products used in the provision of care would help women, and in particular, women-headed households. Finally, decisions to increase the tax take, particularly in times of fiscal constraint, can contribute to the funding of much needed social programmes that can enable women to better balance paid and unpaid work, as well as mitigating the risk of a rise in poverty. 
Other aspects of the taxation system that impact adversely on the tax burden of married women include: (i) allowances or tax deductions granted to the husband, (ii) lack of consideration of childcare costs and (iii) disallowing women to declare their own income (Stotsky, 1996, p. 8). Clearly, the burden of childcare costs remains a persistent barrier to women's engagement in the labour market, and governments' failure to adequately address the issue, through either the tax or welfare system, is deeply problematic for women and families, as well as for economic growth more broadly.

Leaving aside the removal of gender bias in the tax code, primarily through individual filing and elimination of explicit discrimination, there remains the issue of allowances and benefits. While individual taxation is in place, entitlement to benefits by most governments is most often based on joint assessment of their income. This attempt to favour income redistribution within households may have had the effect of reintroducing biases in favour of the traditional division of labour.

\section{Gender budgeting and tax policy}

There is emerging evidence of a trend towards examining tax policy from a gender perspective. Austria has produced regular studies on the impact of its revenue policy on gender equality. More latterly, Spain, Finland and Ireland are among other European countries that have commissioned similar studies.

\section{Austria}

Within the framework of its gender budgeting initiative, the Ministry of Finance in Austria is required to identify a gender equality objective as part of its revenue policy. Currently, that objective is: 'The tax system supports a better distribution of paid and unpaid work between women and men.' Clearly this is not an objective that can be achieved in one budget cycle, nor through any single measure. Thus, the objective will remain relevant for some time to come, with successive budget cycles introducing new measures and refining existing ones towards a progressive realisation of the objective.

Among the measures that will contribute to the objective is a reduced entry-level tax rate of 25 per cent (previously 36.5 per cent). Further, reducing standard tax rates provides relief of 1.3 per cent for the highest incomes, and up to 3.26 per cent for low and middle incomes that exceed the tax threshold. Once the social security 
contribution refund is taken into account, incomes that are just over the lower-earnings limit (Geringfügigkeitsgrenze) will benefit from the highest relief of 4.22 per cent. As higher incomes receive relatively less relief, given the current income differential, the gap between the net disposable incomes of men and women will decline.

Another measure is an increase in the tax allowance for couples with children. Currently, the allowance amounts to $€ 220$ per child, per year. From 2016, the basic benefit will increase to $€ 400$ per child, per year. As part of this reform, the benefit is enhanced when claimed by both partners. This means that irrespective of their individual tax rate, each will be eligible to claim $€ 240$ per child; should only one parent claim, the amount due will be $€ 400$.

\section{Spain}

In its Equal Opportunities Strategic Plan, 2014-2016, the Government of Spain (2014) committed to analysing the impact of taxation and public benefits so as to gauge their influence on women's labour market participation and their 'professional prospects'. The study would also look at how social security regulations impact differently on men and women, and particularly the impact of those regulations related to part-time work.

\section{Finland}

Published in late 2015 the Finnish Government's study on the differential gender impact of tax changes covered the period from 1993 to 2012. Focused primarily on changes in income and consumption taxes, the study also took account of changes in income levels, income distribution and demography. The study reported that the taxation of earned income had decreased by some eight and a half percentage points, with women and men faring more or less equally. With respect to consumption taxes, the study pointed to the challenges of assessing the gender equality impact due to the inability of allocating the taxes to individuals. The many changes - up and down in VAT cancelled each other out and the ratios of taxes on consumption stayed almost unchanged during the period under scrutiny. However, the study was not clear on the gender implications of the distribution of VAT across a range of goods.

\section{Ireland}

A study carried out by the Economic and Social Research Institute investigated the gender impact of tax and benefit policy changes over 
the period from 2009 to 2013 . This was a period of successive austerity budgets in Ireland.

Using a microsimulation model based on a large-scale, nationally representative sample, the study identified the impact of policy changes as distinct from changes in employment, unemployment or pre-tax incomes. Changes in disposable income were measured against a base of 2008, compared to those of 2013.

The research found no sizeable gender difference of the impact of Budgets 2009-13 for single people, with a loss of between 9 and 10 per cent for both men and women. For both single men and women without children, losses were greater at the bottom-income quintile, driven by social welfare reductions, and at the top quintile, where losses related to taxation and public sector pay changes.

One of the main limitations of the research was that it did not take account of (i) the impact of cuts in public services nor (ii) the impact of changes in indirect taxation. Work is ongoing to rework the model to accommodate these dimensions. The study acknowledges that neither of the study scenarios - i.e. full income sharing and no income sharing - is likely to be accurate, but argues that the approach can help to put approximate bounds on the impact of policy. Finally, the study points to the usefulness of this approach to gender budgeting in that the method could be applied ex ante and would allow a gender impact assessment to be built into the budgetary process.

\section{The role of civil society}

Civil society has been a key driver of gender budgeting in Europe. Quinn (2009) details the activities of a number of groups whose work contributed to the emergence of government-led gender budgeting initiatives at both national and regional levels. While civil society fulfils a number of both supportive and critical roles in relation to gender budgeting, it is perhaps its application of gender expertise to economic policy that is of particular importance. At its most basic, the resultant analysis is a straightforward extrapolation of, on the one hand, how men and women contribute to, and are impacted by, the economy, and, on the other, the factors that inhibit or enhance the participation of both men and women towards the realisation of the country's full economic potential. While the analysis challenges certain normative economic assumptions, it is evidence-based, constantly pushing for the use of a wider spectrum of data in economic policymaking. 
The contribution these groups make is vital to the broader project of gender budgeting for at least three reasons: (i) framed as gender mainstreaming, the reach of gender budgeting has largely been restricted to public expenditure, thus leaving many facets of fiscal policy unexamined; (ii) the depth and calibre of the analysis renders the relevance of gender to economic policy indisputable; and (iii) its dissemination among a broad community of academics, policymakers, public representatives and citizens has elevated the debate and educated the debaters.

\section{Conclusions}

Notwithstanding commitments to gender mainstreaming, most EU countries do not design public policies with gender equality as a primary consideration (Daly, 2011). As a consequence, many disparities and inequalities between the sexes have become embedded, to a great or lesser extent, in the baseline of public policies and the allocation of public resources (OECD, 2016). Many countries in Europe are engaged with gender budgeting as a way to redress these disparities and inequalities. Gender budgeting provides an opportunity to apply gender mainstreaming to the normal routines of budgeting and thus help to bridge the gap between policymaking and budget formulation. At the same time, gender budgeting, with its focus on outcomes, is in line with 'modern' budgeting, with the focus on the shift from inputs and outputs to outcomes and the measurement of performance.

Gender budgeting has proven most successful in jurisdictions where it has been underpinned by legislation. In most instances, changes to the OBL, and other finance laws, mean that a gender perspective becomes routine in all aspects of budget formulation, execution and audit. These legal mandates include provisions for an annual gender budget statement to parliament, the collection and management of more sex-disaggregated and gender-relevant data, responsibility for oversight of the gender dimension assigned either to existing budget oversight and audit bodies or to a newly created body, and the inclusion of a gender perspective as part of the regulatory process governing the introduction of new legalisation and government programmes.

One of the leading development economists and chair of the UK Women's Budget Group characterises gender budgeting as bringing 
together two sets of knowledge - knowledge on gender equality and knowledge on public policy and finance - that have hitherto been kept apart. For those responsible for budget formulation, the challenge begins by determining the relevance of gender to the respective policy sectors. Beyond this is analysis from a gender perspective, the identification of gender equality objectives and the reorientation of the budget towards their attainment. The importance of gender expertise to these tasks cannot be overstated. This is particularly so when seen within the context of the traditionally held view of the budget as a gender-neutral, value-free instrument designed towards the provision of public goods of equal benefit to all. Understanding gender - how it is manifest in society and across the policy sectors, how and what data are required, how it can be applied as a category of analysis - is vital if meaningful gender equality objectives are to be elaborated within the budgetary process.

In some countries the need for gender expertise is met in part by aligning existing gender equality goals with gender budgeting goals. The process of drafting the national gender equality strategy has included some degree of consultation, and thus the strategy reflects a high degree of gender expertise. In most instances, where a gender equality strategy is in place, some of the goals articulated overlap with national economic goals. Aligning gender budgeting initiatives with gender equality goals could provide the basis for better gender equality outcomes. Sweden and Finland are good examples where this coordination is in place.

Budgetary and/or governance reforms have provided the stimulus and the framework for the introduction of gender budgeting in a number of countries. This has proven useful and is potentially a productive modality to further explore and exploit. A recent OECD report suggests that a fully implemented gender budgeting regime represents 'an advanced form of PFM [public financial management] reform' (OECD, 2016). In Northern Ireland and Scotland public officials have exploited the respective new governance regimes, with their enhanced mandates to promote equality, to integrate the principle of equality into their budgetary processes.

\section{Recommendations}

As the administration in Ireland explores how to apply equality budgeting, the following could prove useful in clarifying options: 
- Examine the legal changes underpinning gender budgeting in some jurisdictions - for example, Austria, Iceland and the Autonomous Region of Andalucía - with a view to determining an appropriate legislative initiative for Ireland.

- Review the Central Statistics Office's collection and management of sex-disaggregated and gender-relevant data, and determine how the processes can be improved so as to accommodate budgetary decisions.

- The IMF and the OECD have given renewed momentum to gender budgeting. EU institutions are engaged in a number of research initiatives focused on, among other things, how gender budgeting can be applied to its budget. Ireland could seize the opportunity to convene a high-level seminar on the topic and invite high-ranking officials from those countries with sustained gender budgeting initiatives to share their experiences.

- Two mechanisms most commonly associated with gender budgeting are worth consideration: (i) the inclusion of instructions on gender budgeting in the regular budget circular issued by the Ministry of Finance, and (ii) an annual gender budget statement, outlining how the budget has contributed to the attainment of gender equality outcomes, presented to parliament.

- As with most new policy innovations, pilot projects are a useful way of experimenting with available tools and of identifying the most relevant and potentially productive budgetary programmes. 


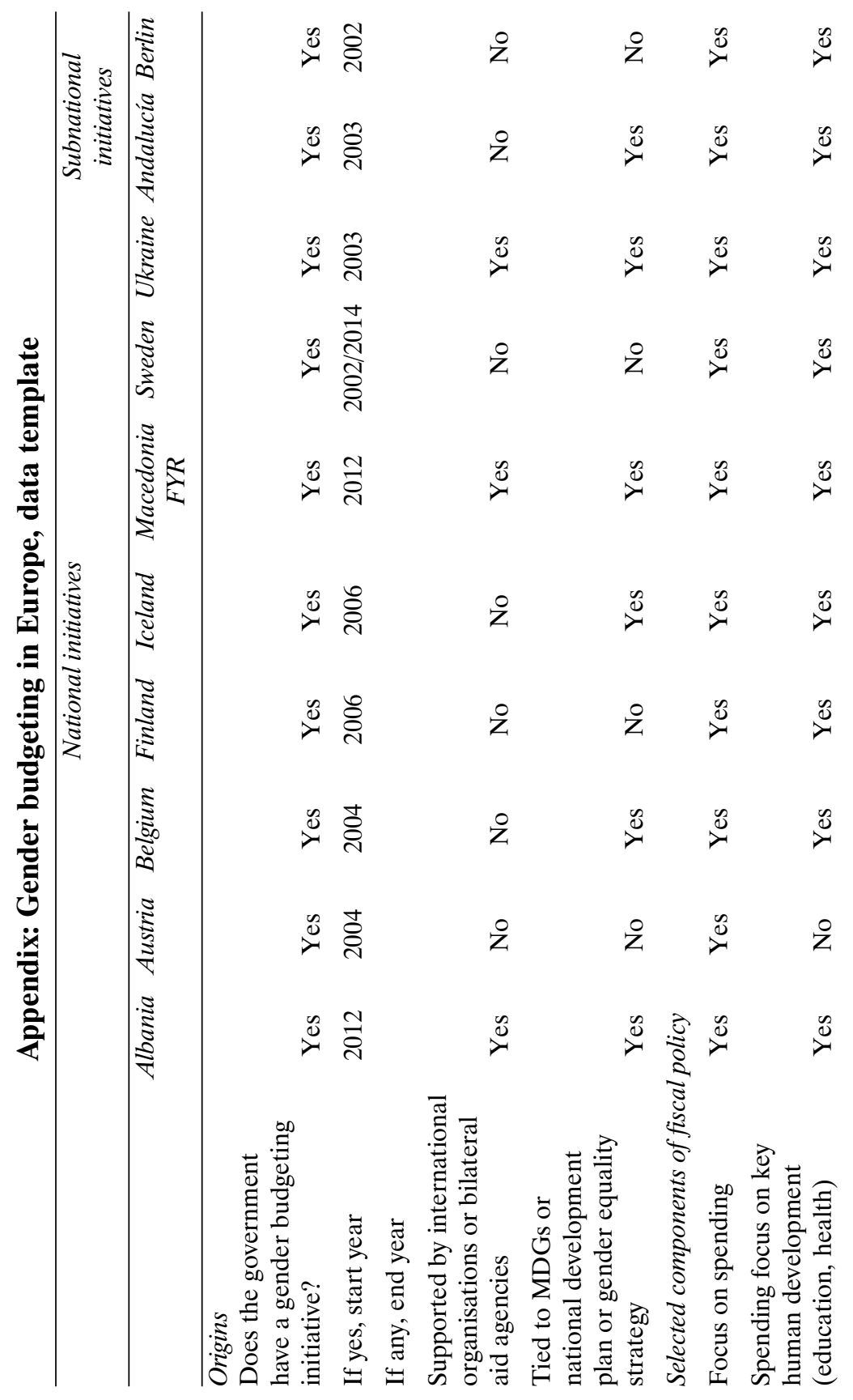




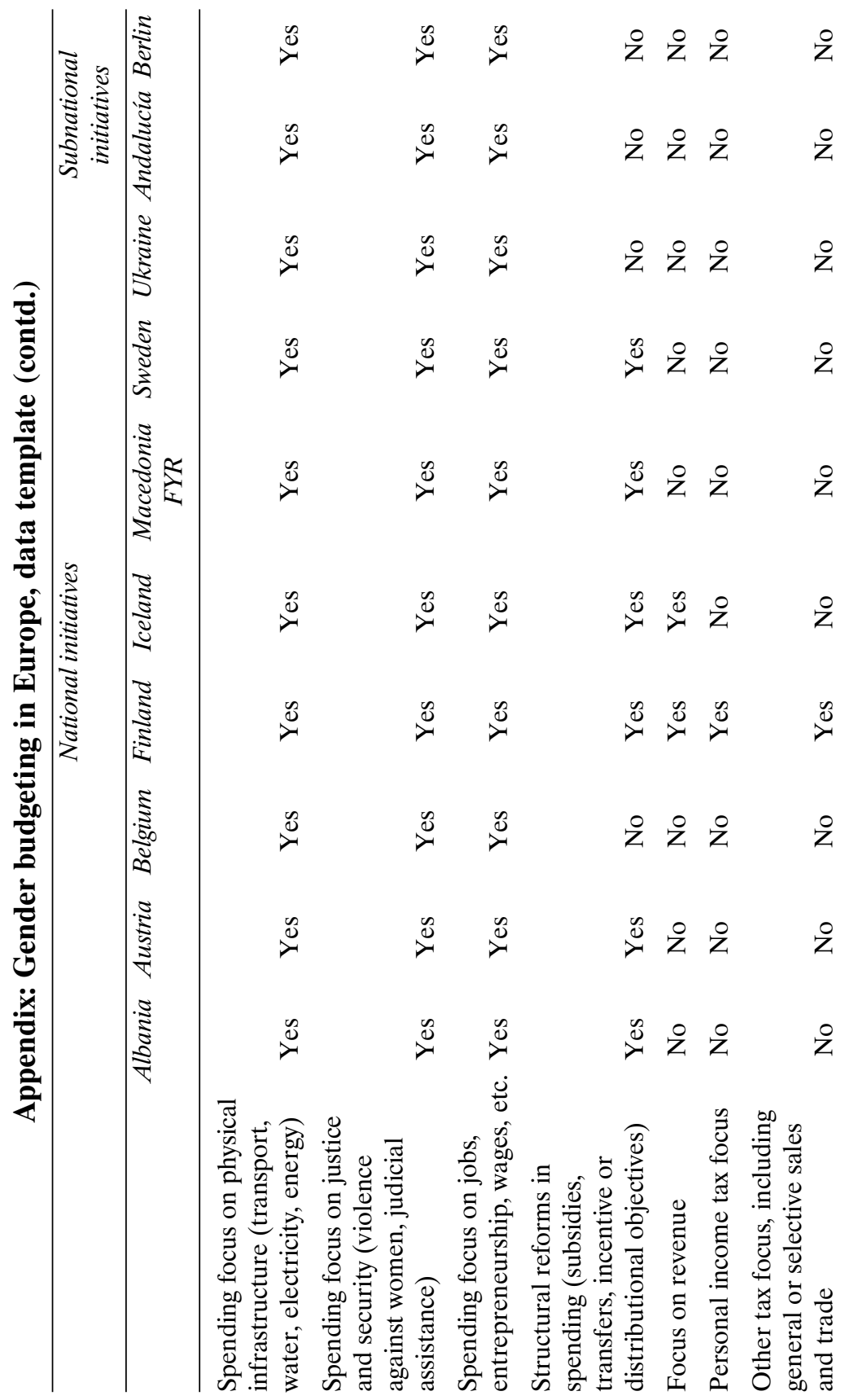




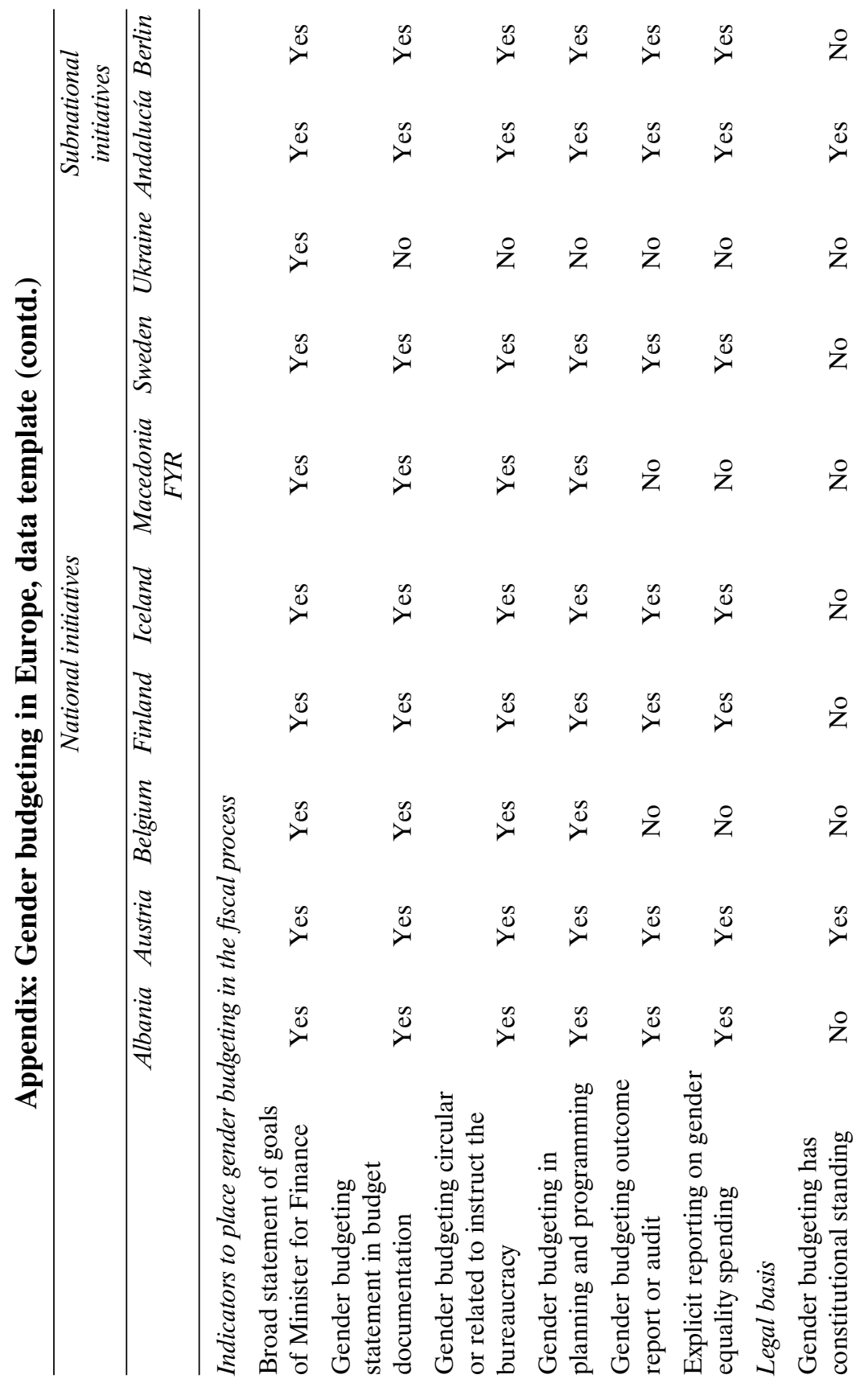




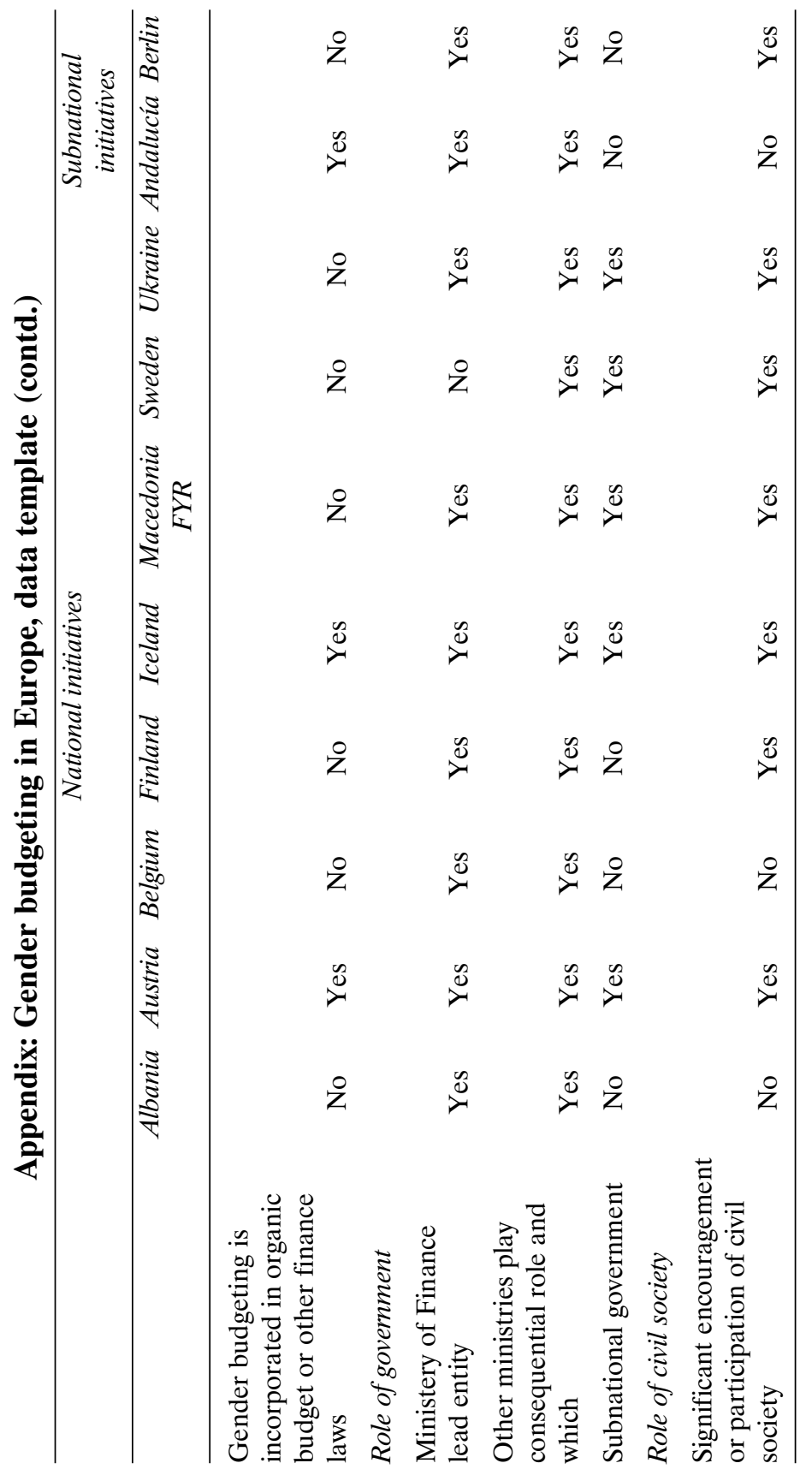




\section{References}

Barry, U. (2014). Gender perspective on the economic crisis: Ireland in an EU context. Gender, Sexuality \& Feminism, 1, 82-103.

Betzelt, S., \& Bothfeld, S. (2011). Incoherent strategies - Fragmented outcomes: Raising women's employment rate in Germany. German Policy Studies, 7, 73-106.

Crouch, C. (2015). Can the European Union abandon social policy? Paper presented at UCD Society of Politics and International Relations 'Understanding the Eurozone Crisis' Seminar Series, November.

Daly, M. (2011). What adult worker model? A critical look at recent social policy reform in Europe from a gender and family perspective. Social Politics, 19, 1-23.

Government Offices of Sweden. (2006). Moving ahead: Gender budgeting in Sweden. Stockholm: Ministry of Integration and Gender Equality.

Government of Iceland. (2011). Implementing gender budgeting: Three year plan. Reykjavík: Ministry of Finance.

Government of Spain. (2014). Equal opportunities strategic plan, 2014-2016. Madrid: Institute for Women and Equal Opportunities under the Ministry of Health, Social Services and Equality.

Grown, C. (2010). Taxation and gender equality: A conceptual framework. In C. Grown \& I. Valodia (Eds), Taxation and gender equity: A comparative analysis of direct and indirect taxes in developing and developed countries. Abingdon: Routledge.

Gualda, R., Jose, M., Aguilera Diaz, B., \& Cirujano Campano, P. (2015). Progress in the Andalusian GRB Practice: Gender budgeting audits. Journal of Economic Policy, 31, 253-71.

Hammerschmid, G., \& Grunwald, A. (2014). Einführung der wirkungsorientierten verwaltungssteuerung: Erfolge - potentiale - perspektiven [Introduction of results-based management control: Success, potential, perspectives]. Vienna: Federal Chancellery.

Holvoet, N. (2006). Gender budgeting: Its usefulness in programme-based approaches to aid. Brussels: European Community Gender Helpdesk.

OECD. (2016). Gender budgeting in OECD countries. Paris: OECD.

O'Hagan, A. (2015). Favourable conditions for the adoption and implementation of gender budgeting: Insights from comparative analysis. Politica Economica, 2, 233-52.

Palier, B., \& Thelen, K. (2010). Institutionalizing dualism: Complementarities and change in France and Germany. Politics \& Society, 38, 119-48.

Quinn, S. (2009). Gender responsive budgeting practical implementation handbook. Strasbourg: Council of Europe.

Quinn, S. (2013). Equality proofing the budget: Lessons from the experiences of gender budgeting. In A. Nolan, R. O'Connell \& C. Harvey (Eds), Human rights and public finance: Budgets and the promotion of economic and social rights. Oxford: Hart Publishing. 
Quinn, S. (2015). The national budget - Forbidden domain: Understanding Germany's rejection of gender budgeting. Masters Thesis, University College Dublin.

Quinn, S. (2016). Europe: A survey of gender budgeting efforts [IMF Working Paper 16/155]. Washington, DC: IMF.

Senate Department for Labor, Integration and Women. (2016). Budget 2016/2017. Berlin: Senate Department for Labor, Integration and Women.

Sharp, R. (2003). Budgeting for equity: Gender budget initiatives within a framework of performance oriented budgeting. New York: United Nations Development Fund for Women.

Sloat, A. (2004). Legislating for equality: The implementation of the EU equality acquis in Central and Eastern Europe [No 8, Jean Monnet Working Papers]. Retrieved from www.jeanmonnetprogram.org [17 July 2017].

Stotsky, J. (1996). Gender bias in tax systems. [IMF working paper 96/99]. Washington, DC: IMF. 